Russell, this unit will be housed in the Rothamsted Experimental Station. Dr. Quastel and his staff will, in the first instance, be engaged mainly in the study of the influence on soil fertility of enzyme systems derived from soil bacteria, or from other microorganisms.

\section{Scientific Films}

THE possibilities of scientific films are immense. They appeal directly to the eye, and their appeal can be reinforced by spoken or printed text. Their capabilities in representing motion enable them to illustrate processes which cannot otherwise be adequately conveyed to the mind. By the control of spoed they can be used to demonstrate actions taking place too quickly or too slowly for the unaided eye to grasp; and the wide possibilities which they offer in magnification and reduction bring processes of nearly all dimensions within the compass of the screen. The mechanism of motion pictures also enables full use to be made of reversal, superimposition and stroboscopic effects in the production of scientific films. Recognition of the value of these films is leading slowly to their use in general scientific education.' Another direction in which their future seems bright, although at present almost unexplored, lies in the popularization of science and in conveying in an acceptable manner some understanding of the relation of science to other forms of human work and culture. A further use of scientific films lies in various fields of research in which permanent records are required of processes in action.

Yet in the sphere of their production, scientific films have many difficulties with which to contend. Their production is scarcely a commercial proposition. They cannot effectively compete with the ordinary popular entertainment films. Also, the technique of their production ealls for highly specialized and gifted talent, not likely to be attracted to the business unless the prospects are good. As a consequence, the number of institutions and organizations showing scientific films is small, and it will not expand rapidly until there is a wider selection of better films to draw upon. To promote the use of such films, the Scientific Films Committee of the Association of Scientific Workers, 30 Bedford Row, London, W.C.1, has recently issued a leaflet on "The Scientific Film", in which a summary is given of the possibilities available in the production and use of films for scientific purposes. This Committee offers its services in the selection of films and in drawing up programmes for different types of audience. Having adopted the practice of viewing scientific films as they become available, the Committee is in possession of information of considerable value to prospective users, and incidentally also to film producers. A small grant from public funds for scientific films would be of great educational worth. In its absence, the field is occupied to a considerable extent by films prepared for commercial and industrial firms, many of which are excellent in themselves, but not entirely free from bias of some kind or other. In spite of this, if full use were made of such films as are available, a great step forward would have been made.

\section{Conditions of the Peking Man Bones}

IT must always come as somewhat of a relief to the ordinary anthropologist that quite ordinary explanations are adequate to account for conditions to which more romantic solutions have been attached. It is, therefore, with some sense of thankfulness that we learn that Prof. F. Weidenreich has decided ("The Extremity Bones of Sinanthropus Pekinensis." Paleontologia Sinica. New Series D. No. 5. Peking: Geol. Survey of China) that the breaking of certain limb bones of Sinanthropus in the caves of Choukoutien has been due to the activities of the hyæna rather than, as he formerly postulated, to a series of cannibal feasts on the part of Peking man. He still believes it necessary, however, to invoke the assumption "that Carnivores and man competed in the breaking of bones both human and animal". May it not be possible that Carnivores have also produced the broken condition of the skulls ? In another way this latest publication on Sinanthropus is pleasing, for it makes it quite evident that the Peking man's femur "is identical with the human femur in size, form, proportions, and character of the muscular markings, differing in all these features from the anthropoid thigh bone in much the same way as any human femur". It is also certain that his humerus is exactly as it is in modern man : and the same applies to the only two other limb bones so far discovered---the clavicle and the os lunatum. For some, it may be rather a descent to earth, but for the science of physical anthropology it is surely a gain that we are at length permitted to know that Sinanthropus possessed the most ordinary and typically human limb bones, and that he walked as upright as the best of us.

\section{Scottish Rock Carvings}

THE September issue of Antiquity contains a note by Prof. V. G. Childe on some finds of rock carvings in Scotland. Two of these are in Argyll and one in Midlothian. The first photograph shows a hind engraved in outline from Gleann Domhain, Argyll. The figure is in profile, two long ears appearing side by side and only two legs. There is a blunt and intriguing tail and an eye is shown. The style of this engraving reminds one forcibly of the Arctic culture rock drawings of Norway and Sweden (Scandinavian Art Group I). Prof. Childe's second photograph is of a fish which has been found near Roslin, Midlothian. This carving is not merely an outline but rather appears to be done in low relief and it, too, might have links with Scandinavia. Not so the third find, of a stylized, rather shapeless, animal figure from Dunadd, Argyll, which is very different in style from either of the other two and might easily belong to a different and later culture group.

The influence of the Scandinavian Arctic Cultureitself probably an offspring of the northern Mesolithic civilization-on eastern Britain has long been suspected, suggested by certain finds of stone implements as well as by the engraving on a piece of flint crust which was found in the earliest levels at Grimes Graves. The new Scottish discoveries, especially the Gleann Domhain hind, powerfully reinforce this 
notion, and even go farther with the inference that the Arctic Culture not only reached our eastern coasts, but indeed, penetrated considerably inlandat least in the northern areas of Britain.

\section{Corrosion in Steel Chimneys}

In the last twenty years, developments in the size and efficiency of boiler plants have led to the abandonment of huge masonry chimneys serving a number of boilers in favour of a separate chimney for each boiler. In Engineering of September 12, Mr. A. V. Staniforth shows that this has been brought about not only for the sake of the advantages accruing during overhaul and repair from such sectionalizing, but also because the very large units, now common, call for much larger chimney areas. The normal chimney was built of lapped riveted plates, but corrosion was found to be very rapid. At one large power station, five steel stacks, each $7 \mathrm{ft} .6$ in. in diameter by $80 \mathrm{ft}$. high, constructed of $\frac{3}{8}$-in. mild steel plates riveted together, had corroded away in parts to paper thickness in five years in spite of annual internal and external cleaning and painting. In all cases the corrosion had become most serious at, and had undoubtedly started from, the joint laps and rivet heads, and was most marked in the upper parts of the chimney. The temperature of the gas entering the chimneys was about $250^{\circ} \mathrm{F}$., at which the steel temperature, particularly near the top of the chimney, often fell below dew point, especially during the colder periods of the year. This caused the deposition of moisture, sometimes increased by rainfall. Combining with the sulphurous gases, it formed sulphurous acid which attacked the steel. The moisture running down the chimney collected along the joint laps and rivet heads, and thus was responsible for the especially severe corrosion at these points.

In solving the problem it was considered desirable first to eliminate the points of corrosion, namely, the lapped joints and rivets, and secondly to find some type of lining which would afford adequate protection to the steel plates. Modern developments in electric welding suggested the use of welded butt joint chimneys, which are easy to construct and give a smooth parallel barrel free from all foci for corrosion. In protecting the interior of the chimney plates from corrosion, asbestos sheeting of certain types was found reasonably suitable. The five steel stacks mentioned above were replaced by lined stacks in 1935 , and five years later a section of the lining was removed from one of the stacks. It was then found that no corrosion of any kind had taken place and that the mill scale was still on the steel. Another advantage is that the heat-insulating effect of the lining cuts down the heat loss, and so the period during which the temperature of the steel falls below the dew-point is very much reduced. Tests showed that with a gas temperature of $290^{\circ} \mathrm{F}$., the outside temperature of an unlined stack was $210^{\circ} \mathrm{F}$., while the lined stack had an outside temperature of $150^{\circ} \mathrm{F}$. The lower outside temperature of the stack reduces considerably the cost of maintenance of the outside of the chimney by increasing the life of painting.

\section{Health of Hawaii}

According to the report of the Board of Health of Hawaii for the fiscal year, the lowest death-rate ever recorded for these islands, namely, $7 \cdot 18$ per 1,000 inhabitants, occurred in 1940. There were 3,025 deaths in a population of 423,332 , the chief causes being heart disease, cancer, congenital malformation and disease, tuberculosis and nephritis. Pneumonia dropped from the second to the eighth leading cause of death, a fact which was attributed to the use of serum and sulphapyridine, which were distributed free to practitioners for the medically indigent. The birthrate was $22 \cdot 62$, as compared with $21 \cdot 79$ in 1939 . An outbreak of 101 cases of infantile paralysis with 10 deaths occurred during the year. The death-rate from tuberculosis was $63 \cdot 2$ per 100,000 , the lowest on record. There were 56 cases of typhoid fever, which were attributed principally to carriers; no cases were traced to milk or to the potable water. There were 77 cases of typhus with 1 death. There were 1 case of human plague which ended fatally and 47 cases in rodents as compared with 129 the previous year.

\section{Announcements}

The Lister Medal for 1942, which is given in recognition of distinguished contributions to surgical science, has been awarded to Prof. Evarts A. Graham, professor of surgery in Washington University, and he will deliver the Lister Memorial Lecture in 1942, or later, under the auspices of the Royal College of Surgeons of England. This is the seventh occasion of the award, which is made by a committee representative of the Royal Society, the Royal College of Surgeons of England, the Royal College of Surgeons in Ireland, the University of Edinburgh, and the University of Glasgow.

IT has been decided not to award any Nobel Prizes this year.

The Tenth International Ornithological Congress, which was to have been held in the United States in 1942 , has been indefinitely postponed.

A Malaria survey of Trinidad was recently begun under the supervision of Dr. Mark F. Boyd and Dr. W. G. Davis of the Rockefeller Foundation.

Messrs. Rowntrees, of York, have made a grant to Dr. F. C. Happold, reader in biochemistry in the University of Leeds, of $£ 150$ a year for two years for research work on nutritional problems.

Erratum.-It was stated in Nature of October 18, p. 457 , that Dr. E. Kodicek, who contributed a paper on post-war relief at the recent British Association meeting, was formerly lecturer in psychology in the University of Prague; this is incorrect. He held the position of head of the Department for Vitamins and Hormones at the University Clinic, Charles University, Prague. 